J. Product. \& Dev., 18(1):47- 56(2013)

\title{
EFFECT OF INDOL ACETIC ACID AND INDOL BUTRIC ACID ON THE YIELD AND BIOCHEMICAL CONSTITUENTS OF CORN GRAINS.
}

A. Sharaf and R.A. Saber

Department of Soil and Water, Faculty of Technology and Development, Zagazig Univeristy, Zagazig. Egypt.

\section{ABSTRACT}

A field experiment was conducted at Ghazala farm to study the effect of indol acetic acid (IAA) and indol butric acid (IBA) on the yield and some biochemical constituents in corn grains.

The results of this study can be summarized as following:-

All treatments increased the grain yield of corn, but using a mixture of both hormones is more effective than the use of a single one. Spraying IAA or IBA had an increase on non-soluble nitrogen fraction, but the soluble nitrogen was decreased. The highest increase of total and insoluble carbohydrates were recorded at 50 and 100 ppm IBA. All treatments decreased the percentage of oil in corn grains when was the mixture of 50 ppm IAA and IBA. The total free amino acids were slightly decreased by the used IBA treatments, whereas, the second level of IAA and a mixture of $50 \mathrm{ppm} I A A .+50 \mathrm{IBA}$ caused an increase of total amino acids in corn grains. Both IAA or IBA decreased the $P$ and $K$ content of corn grains, especially when, IBA applied.

In conclusion, spraying corn plants with a mixture of (IAA) and (IBA) increase the yield, soluble, insoluble nitrogen and slightly increase the total contents of amino acids, but decrease total content of carbohydrate, the percentage of oil contents. Also the net result recorded that spraying corn plants with 50,100 ppm (IAA) increased yield, total nitrogen content, total carbohydrate content, total amino acid content in case of spray[ng byl00 ppm, but decease the total content of oils, while in case spraying by of 50,100 ppm ( IBA) will increase yield, nitrogen contents, total carbohydrates, but decrease the total amino, and oil contents. All treatment application decreased $(P)$ and $(k)$ contents.

Key words: Indol acetic acid, indol butric acid, yield \& biochemical constituents, corn grains.

\section{INTRODUCTION}

Seeds have been of interest to man for along time. The early inters were largely of a practical nature since seeds are a major source of food in 
most parts of world. Consequently, information on seeds concerns their nutritive value and chemical composition and so forth. As pressure has developed for increased food production throughout the world the use of improved and superior seeds has been stressed. Similarly, the needs for other seed products such as oils. Fibers and industrial chemicals have created additional demands for new seed varieties (Ingle et al., 1965). So, corn plant is one of the fundamental sources of diet for human and animal consumption, therefore many attempts were done to increase the yield of grains or to improve the quality of its protein and carbohydrates.

Growth regulators have been used on a large scale in recent year in studying the development and productivity of plant. It has been established as a result of numerous studies, that plant hormone is a substance possessing high physiological activity and that it exercises multilateral influence on plants. In this connection, Allam (1983) found that some growth regulators and micronutrients increase the content of nitrogen, carbohydrates and grain yield of maize. Also, Taira et al. (1979) detected significant differences in seed protein and carbohydrate contents as affected by different rates of foliar hormones. Also, Amal et al. (2009) found that the application of ASA and IBA enhanced plant growth fresh, dry weight and significant increase in 1000 seeds weight. Also found that ,the soluble protein ,total soluble carbohydrates and sugars were increased by ASA and IBA application. Exogenous IAA significantly increased $\mathrm{Pb}$ accumulation in roots, but decreased $\mathrm{Pb}$ accumulation in shoots over the culture period of fife days, Huan et al (2007). Also, Jutta et al. (1997) found that the increase in IBA was accompanied by an increase of sythetase activity, but the enzyme activity was also enhanced at later stages infection .

Therefore, the aim of the present study was to evaluate the effect of IAA and IBA either applied individually or as a mixture on yield and some biochemical constituents of corn grains. Amin et al. (2007) reported that the foliar application of IBA and SA with different concentration led significant increases fresh, dry weight, photosynthetic pigments contents of leaves, yield and quality as will as biochemical constituents of onion bulb.

\section{MATERIALS AND METHODS}

The field experiment was conducted in the Agronomy farm of Ghazala, Zagazig, Sharkia Governorate at 2010 / 2011 season. A complete randomized block design was applied. Each treatment was replicated three times. Foliar hormones were applied as follow:

1- Control 2- 50 ppm IAA 3- 100 ppm IAA -4- 50 ppm IBA 5- 100 ppm IBA 6- 50 ppm + 50 ppm IBA 7- 100 ppmIAA+100 ppmIBA. 
- The growth hormones under investigation were applied as foliar after 25 days of sowing date. At full Maturity, the yield was determined, and samples were collected dried at 70c the grounded and stored until chemical analysis.

\section{Methods of analysis}

- Total nitrogen in samples of corn grains was determined according the method described by A.O.A.C. (1970).

- Soluble nitrogen was determined in the samples according to the method described by Mengle and Helal (1968).

- Carbohydrates were determined according to the method of Magnetski et al. (1959).

- Phosphorus determined according to the method adapted by Agiza et al. (1960).

- Potassium was determined using the atomic absorption apparatus in the acid dighest according to the method of Chapman and Parker (1961).

- The oil percentage was determined by extracting the oil in sixhelt apparatus by petroleum either according to the method described by A.O.A.C. (1970).

- The free amino acids were extracted, fractionated and determined by Block and Durrn (1958).

\section{RESULTS AND DISSCUSSION}

As illustrated in Table 1, the application of indole acetic acid (IAA) has an increasing effect on corn grains yield. On the other hand, the interaction effect of IAA and IBA on the grain yield is more effective on grain yield than the application of each hormone. Also, the data in the same Table (1) showed that the first level $(50 \mathrm{ppm})$ and second level $(100 \mathrm{ppm})$ of IBA slightly decreased the grain yield when compared with control. The results could be due to the biological effect of IAA on the Photosynthesis activation during growth. The same conclusion was stated by Amin et al. (2007) and Vahid et al. (2012) reported that application of IBA and increased the grain yield and yield

Table 1. Effect of Indol Acetic and Indol Buteric Acid On the yield of Corn Grains

\begin{tabular}{|c|c|c|c|c|}
\hline Treatments & Gm/plant & $\begin{array}{c}\mathrm{Kg} / \mathrm{plot} \\
1 / 300 \text { fedd }\end{array}$ & Kg/fedd & $\begin{array}{c}\text { Weight of 100 } \\
\text { kernel Gm }\end{array}$ \\
\hline 1-Control & 210 & 16.90 & 5070 & 24.88 \\
\hline 2-50 ppm IAA & 227 & 18.43 & 5553 & 27.42 \\
\hline 3-100 ppm IAA & 236 & 19.78 & 5934 & 26.82 \\
\hline 4-50 ppm IBA & 205 & 16.45 & 4935 & 24.66 \\
\hline 5-100 ppm IBA & 212 & 17.08 & 5124 & 25.12 \\
\hline 6-50 ppm IAA+IBA & 243 & 19.92 & 5976 & 27.16 \\
\hline 7-100 ppm IAA+IBA & 235 & 19.22 & 5766 & 26.99 \\
\hline $\begin{array}{ll}\text { L.S.D } & 5 \% \\
& 1 \% \\
\end{array}$ & - & $\begin{array}{l}0.685 \\
0.960\end{array}$ & - & - \\
\hline
\end{tabular}


components of corn plant.

The weight of 100 kernels the data revealed that it was generally increased as a result of all treatments except treatment with $50 \mathrm{ppm}$ of IBA The highest weight of 100 kernels was obtained by a mixture of 50 ppm IAA $\& 50$ ppm IBA.

Data presented in Table (2) indicated that there was a slight increase in insoluble and total nitrogen in corn grains from plants treated with IBA at the low and high levels. The highest increased noticed with second level of IAA (100 ppm), when compared with other treatment. This is probably due to that IAA induced protein synthesis. These results agree with these reported by Sharaf and El-Saadany (1982) and Amal et al (2009) who found that the protein content in wheat grains was increased with foliar application of plant hormones.

Table 2. Effect of indol acetic and indol buteric acid on the content of nitrogen fraction in corn grains

\begin{tabular}{|c|c|c|c|c|}
\hline Treatments & $\begin{array}{c}\text { Sol. } \\
\text { N }\end{array}$ & $\begin{array}{c}\text { Insol } \\
\mathbf{N}\end{array}$ & $\begin{array}{c}\text { Total } \\
\text { N }\end{array}$ & $\begin{array}{c}\text { Ratio } \\
\text { Sol./Insol }\end{array}$ \\
\hline 1- Control & 0.168 & 1.325 & 1.493 & 0.127 \\
\hline 2- 50 ppm IAA & 0.150 & 1.534 & 1.684 & 0.098 \\
\hline 3- 100 ppm IAA & 0.146 & 1.846 & 1.992 & 0.079 \\
\hline 4- $50 \mathrm{ppm}$ IBA & 0.184 & 1.316 & 1.500 & 0.139 \\
\hline 5- 100 ppm IBA & 0.188 & 1.397 & 1.585 & 0.126 \\
\hline 6- 50 ppm IAA+IBA & 0.175 & 1.611 & 1.786 & 0.108 \\
\hline 7- $100 \mathrm{ppm}$ IAA+IBA & 0.192 & 1.566 & 1.758 & 0.123 \\
\hline
\end{tabular}

From the same Table (2), treating plants with I.B.A increased the soluble nitrogen fractions but slightly decreased the insoluble nitrogen in corn grains as compared to control. On the other hand, spraying corn plants with a mixture of both hormones caused an increase in the nitrogen fraction as compared with control. This may be explained on the bases that plant hormones the nitrogen fixation as well as the synthesis of insoluble nitrogen fractions such results agree with those obtained by Doheem et al. (1982), who found that the nitrogen fractions were increased by $\mathrm{GA}_{3}$ and Kinetin hormones applied. Also, Amal et al (2009) found that IBA stimulate and promote plant protein. The sol. N/insol. $\mathrm{N}$ ratio was reduced by spraying two levels of IAA and mixture of two hormones used on corn plant. Also, the ratio sol. /insol. $\mathrm{N}$ was increased by IBA treatments, it can not be taken as an evidence of reduced protein synthesis since the increase in soluble protein did not occur on the expense of the insoluble. These results are in agreement with those obtained by Vahid et al. (2012) and Amal et al.(2009).

Results in Table (3) concerning with the effect of IAA and IBA spraying on the content of amino acids in corn grains affected by some plant hormones are shown in Table 3. The free amino acids in corn grains were, 
alanine, glycine, valine, tyrosine, phenyl alanine, glutamic, aspartic, lysine and methionine.

The data in Table (3) showed that, spraying corn plant with IBA at different concentrations the total free amino acids in corn grains except when sprayed plants with (100 ppm IAA+100 ppm IBA). While, it can be noticed from the same Table that all treatments with IAA increased the total free amino acids in corn grains. Also, it can be noticed that, the aliphatic amino acids showed comparatively the highest values among the other amino acids. As well as, the phenylalanine content was higher than tyrosine content in grains. These results are in full agreement with those obtained by Huan et al. (2007)and Jutta et al.(1997)

The results in Table (4) show that, the foliar hormones increased the carbohydrate content of corn grains. The greatest increase of insoluble or total carbohydrates were recorded at $100 \mathrm{ppm}$ IBA. While, the lowest increase was obtained at $50 \mathrm{ppm}$. IAA. This means that the used of IBA increased the photosynthetic processes and finally reflected on carbohydrates content . These results are in agreement with those obtainad by Amal et al. (2009).

Table 4. Effect of indol acetic acid and indol buteric acid on the content of carbohydrate fractions in corn grains

\begin{tabular}{|l|c|c|c|c|}
\hline \multicolumn{1}{|c|}{ Treatments } & $\begin{array}{c}\text { Soluble } \\
\text { Carbohydrate }\end{array}$ & $\begin{array}{c}\text { Insoluble } \\
\text { Car. }\end{array}$ & $\begin{array}{c}\text { Total } \\
\text { Car. }\end{array}$ & $\begin{array}{c}\text { Ratio } \\
\text { Sol./Insol }\end{array}$ \\
\hline 1- Control & 12.93 & 64.49 & 77.42 & 0.200 \\
2- 50 ppm IAA & 11.73 & 66.52 & 78.25 & 0.176 \\
3- 100 ppm IAA & 11.84 & 67.14 & 78.98 & 0.176 \\
4- 50 ppm IBA & 11.29 & 69.34 & 80.68 & 0.162 \\
5- 100 ppm IBA & 12.13 & 68.75 & 80.88 & 0.176 \\
6- 50 ppm IAA+IBA & 12.71 & 67.77 & 79.48 & 0.178 \\
7- 100 ppm IAA+IBA & 12.71 & 66.95 & 79.66 & 0.189 \\
\hline
\end{tabular}

Data in Table (5) indicated that oil content of corn grains was decreased at treatments of IAA or IBA as compared with control. The highest decrease in oil content of corn grains was recorded at the first level of IBA or the first level of a mixture IAA and IBA. These results are in agreement with those obtained by Doheem et al. (1985). Also, the oil properties of corn grains, Acid value, saponification value and Iodine values did not show any effects except at 100 ppm IBA or a mixture of two hormones showed a slight increase of acid value in the oil of corn grains.

The results in Table (6) showed the effect of IAA and IBA treatments on the content of $\mathrm{P}$ and $\mathrm{K}$, in corn grains. Phosphorus and Potassium content in corn grains decreased by foliar application of all treatments, when compared with control. 
Table 5. Effect of indol acetic and indol buteric acid on the content and some properties of oil in corn grains

\begin{tabular}{|l|c|c|c|c|c|}
\hline \multirow{2}{*}{ Treatments } & \multicolumn{2}{|c|}{ Oil Content } & \multicolumn{3}{c|}{ Some Properties } \\
\cline { 2 - 6 } & $\%$ & $\mathbf{m g m} /$ plant & $\begin{array}{c}\text { Acidic } \\
\text { value }\end{array}$ & Sapon.value & $\begin{array}{c}\text { Iodine } \\
\text { value }\end{array}$ \\
\hline 1- Control & 0.045 & 9.45 & 0.65 & 182.6 & 143.6 \\
2- 50 ppm I.A.A & 0.034 & 7.72 & 0.65 & 182.8 & 148.7 \\
3- 100 ppm I.A.A & 0.040 & 9.44 & 0.65 & 184.1 & 148.6 \\
4- 50 ppm I.B.A & 0.029 & 5.95 & 0.66 & 183.2 & 148.5 \\
5- 100 ppm I.B.A & 0.024 & 6.15 & 0.68 & 183.4 & 148.8 \\
6- 50 ppm I.A.A+I.B.A & 0.026 & 6.32 & 0.67 & 183.6 & 148.8 \\
7- 100 ppm I.A.A+I.B.A & 0.032 & 7.52 & 0.68 & 183.4 & 148.6 \\
\hline
\end{tabular}

Table 6. Effect of indol acetic and indol buteric acid on the content of phosphorus and potassium on corn grains ( $\mathrm{mg} /$ plant)

\begin{tabular}{|l|c|c|c|c|}
\hline \multirow{2}{*}{ Treatment } & \multicolumn{2}{|c|}{ Phosphorus } & \multicolumn{2}{c|}{ Potassium } \\
\cline { 2 - 5 } & $\mathbf{\%}$ & $\mathbf{m g m} /$ plant & \% & mgm/plant \\
\hline 1- Control & 1.965 & 454.65 & 3.689 & 774.69 \\
2- 50 ppm IAA & 1.405 & 318.94 & 3.175 & 722.99 \\
3- 100 ppm IAA & 1.481 & 349.75 & 3.221 & 760.36 \\
4- 50 ppm IBA & 1.405 & 258.03 & 3.625 & 743.12 \\
5- 100 ppm IBA & 1.342 & 284.57 & 3.444 & 708.99 \\
6- 50 ppm IAA+IBA & 1.689 & 410.43 & 3.067 & 760.59 \\
7- 100 ppm I.A.A+I.B.A & 1.785 & 419.47 & 3.246 & 762.75 \\
\hline
\end{tabular}

The highest decrease of phosphorus or potassium content in corn grains was noticed at $100 \mathrm{ppm}$ IBA. In this connection, Gaber, et al, (1983), found that plant hormones decreased the percentage of phosphorus in plants. Also, the spraying plants with IB.A either at $50 \mathrm{ppm}$ or at $100 \mathrm{ppm}$ gave the highest decrease of $\mathrm{P}$ contents in corn grains when compared with the control and other applications.

In conclusion, spraying corn plants with a mixture of (IAA) and (IBA) increase the yield, soluble ,insoluble nitrogen and slightly increase the total contents of amino acids, but decrease total content of carbohydrate, the percentage of oil contents. Also the net result recorded that spraying corn plants with 50, $100 \mathrm{ppm}$ (IAA) increased yield, total nitrogen content, total carbohydrate content, total amino acid content in case of spray[ng by $100 \mathrm{ppm}$ ,but decease the total content of oils, while in case spraying by of 50,100 ppm (IBA) will increase yield, nitrogen contents, total carbohydrates, but decrease the total amino, and oil contents. All treatment application decreased $(\mathrm{P})$ and $(\mathrm{k})$ contents. 


\section{REFFERENCES}

Agiza, A.H., El-Henedy, Y. and Ibrahim, M. (1960). The determination of the different fractions of Phosphorus. Faculty Of Agric., Cairo Univ., Bill No. 121- 127.

Allam, S.A. (1983).Study on the effect of some growth regulators and Micronutrients on growth and yield of Maize. M. Sc. Thesis, Zagazig Univeristy, Zagazig, Egypt.

Amal M. El- Shraiy and Amira M. Hegazi(2009). Effect of Acetylsalicylic Acid, Indole-3- Bytric Acid and Gibberellic Acid on Plant Growth and Yield of Pea (Pisum Sativum L.). Australian Journal of Basic and Applied Sciences, 3(4): 3514-3523.

Amin A. A., EL-Sh. 11 M. Rashad and 2H.M.H. EL-Abagy (2007). Physiological Effect of Indole - 3 - Butyric Acid and SalicylicAcid on Growth, Yield and Chemical Constituents of Onion Plants. Journal of Applied Sciences Research, 3(11): 1554-1563,

A.O.A.C. (1970). Official and Tentative methods of analysis. Association of official Agricultural Chemists. Washington, D.Ci, 11 ed.

Block, R.J. and Durrm, S.L (1958). Chromatography And Electrophoresis. Acad. Press Inc. New York.

Chapmann, H.D. and Parker, F.P. (1961). Methods Of Analysis Of Soil, Plant And Water. Univ. of California. August, $19812^{\text {nd }}$, printing.

Doheem, M., Sharaf, A., El-Massry, R. and Youssef. A. (1982). Effect of some plant hormones on protein metabolism in Phaseotus valgaris. Zagazig Jour. Agric. Res., 7:388- 409.

Doheem, M., Sharaf, A., Sotohom, and Abd-Elmaksod, H., (1985). Biochemical effect of Antitanspirant on some biochemical constituents of seeds plant. Zagazig Jour. Agric. Res., 9 (2) 373 -391

Gabr, S., Sharaf, A. and El-Saadany, S. (1983). Effect of cycocyl and alar on some Biochemical constituents in tomato plants. Annals of Agric. Sci, Moshtohor, 20: 61-71.

Huan-hua.W,Xiao.Q,S;Bei.W; Gary.O,J.F and Shu-Z.Z.(2007). Effect of indol -3-acetic acid on lead accumulation in maize(Zea mays) L).Environmental and Experimental Botany, 61:246-253.

Ingle , J . D . Beitz and R .H. Hageman (1965). Changes in composition during development and maturation of maize seeds. Plant Physiol.,40:835-839 .

Jutta ,L.M.; Michael,K.; Ellen,G.S. and Ephraim,E.(1997). Indole -3- butric acid(IBA) is enhanced in young maize (Zea -mays-L.) roots colonized with the arbuscular mycorrhizal fungus Glomus intrardices. Plant Science, 125:153-162. 
Magnetski, K.P., Tsugarov, Y.A. and Malkov, B.K. (1959). New Methods For Plant And Soil Analysis. U.M.B. Rell - Paris - Stauffer.

Mengle, K. and Helal, M. (1968).The effect of varied nitrogen and Potassium nutrition on the content of soluble amino compounds in serial parts of oats. Z.flanzener nacher Bodenk, 122 (1): 12-20.

Sharaf, A. and El-Saadany, S.S. (1982). Effect of different levels of Kinetin and $\mathrm{GA}_{3}$ on some biochemical constituents of wheat. Zagazig Jour. Agric. Res., 9 (1): 280-299. .

Taira, H., Asahi, Y. and Iguch, T. (1979). Report of National food institute No. 35: 42-47.

Vahid, G,. Mohammad J., Mohammad, S. and Abbas K. (2012). Yield and Yield Components of Corn (Zea mays L.) In Responseto Folia Application with Indole Butyric Acid and Gibberellic Acid, AmericanEurasian J. Agric. \& Environ. Sci., 12 (9): 1246-1251. 


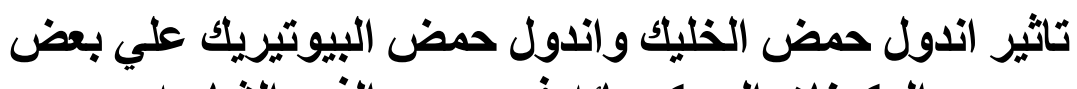
المكونات البيوكيميائه في حبوب الأرل حمب البوه الثاميه

$$
\text { عبدالززيز لطفى شرف - ر رفعت صابر }
$$

قسم الأر اضي والمياه ـ كلية التكنولوجيا والتتمية - جامعة الزقازيقـ الزقازيق- مصر.

اجريت تجربة حقلية في مزر عة كلية التكنولوجيا والتتمية بقرية غز اله التابعة لمركز

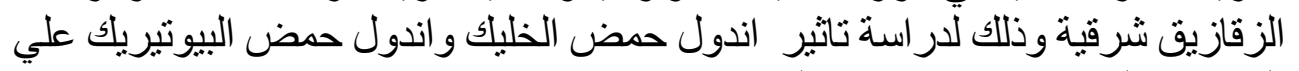

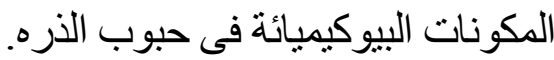

$$
\begin{aligned}
& \text { ووضحت النتائج الاتي :- }
\end{aligned}
$$

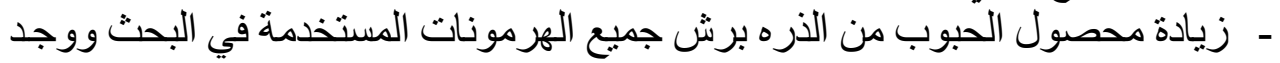

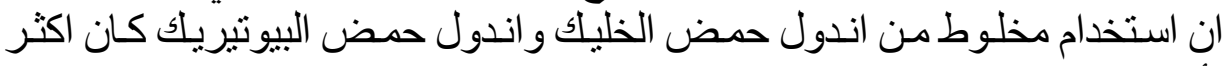
تأثير ا.

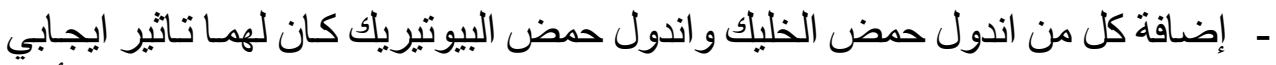

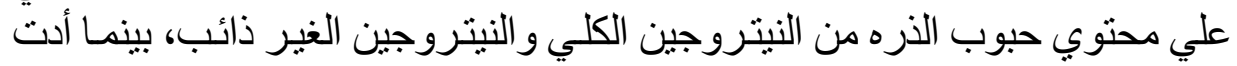

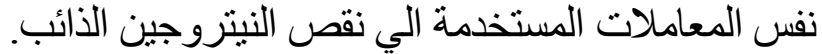

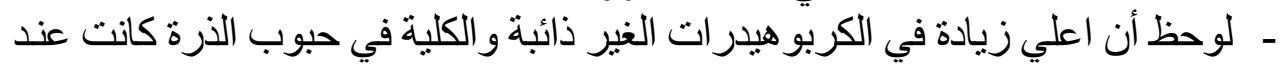
استخدام معاملات اندول حمض البئ البيوتيريك.

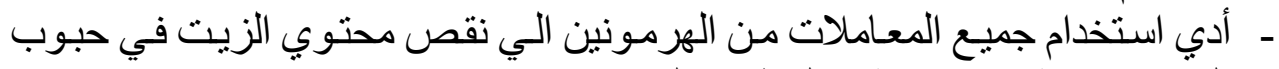

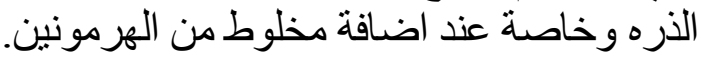

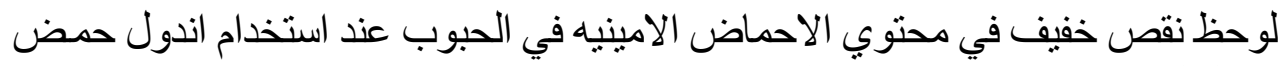

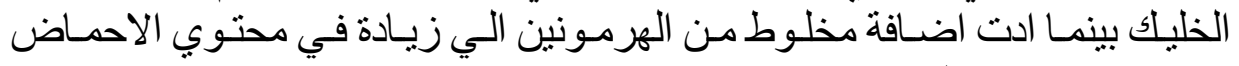

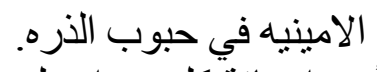

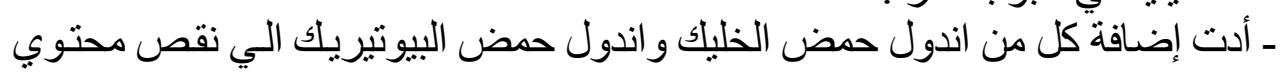

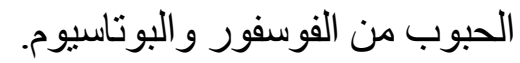

